\title{
The City Public Transport Overlooked: Analysis of Effective Distances
}

\author{
Orit Rotem-Mindali', Eran Feitelson' ${ }^{2}$, Yaron Michael' \\ ${ }^{1}$ Department of Geography and Environment, Bar Ilan University, Ramat Gan, Israel \\ ${ }^{2}$ Department of Geography, The Hebrew University of Jerusalem, Jerusalem, Israel \\ Email: orit.rotem@biu.ac.il
}

How to cite this paper: Rotem-Mindali, O., Feitelson, E. and Michael, Y. (2017) The City Public Transport Overlooked: Analysis of Effective Distances. Journal of Geographic Information System, 9, 663-684. https://doi.org/10.4236/jgis.2017.96042

Received: October 17, 2017

Accepted: November 28, 2017

Published: December 1, 2017

Copyright $\odot 2017$ by authors and Scientific Research Publishing Inc. This work is licensed under the Creative Commons Attribution International License (CC BY 4.0).

http://creativecommons.org/licenses/by/4.0/

\begin{abstract}
Jerusalem is holy to the three main monotheistic religions. Hence Jerusalem is, from a touristic perspective, a world city. Jerusalem is also a highly segmented city. While Jerusalem may seem as an extreme case, it is not unique. Many cities attract large number of tourists to various widely renowned sites within them, in many cases with religious facets. Public transport systems are largely designed to address the demand of local residents. Yet, tourist flows often differ from the travel patterns of local residents, both temporally and spatially. This paper evaluates how Jerusalem's public transport system serves the global tourist city. To this end, the study focuses on independent tourists, not package-tour tourists. Specifically, we analyze to what extent are the main tourist sites served by the public transportation system. To evaluate accessibility to tourist destinations we use GIS to conduct Least-Cost-Modeling. This methodology measures the effective, rather than the Euclidian distance to tourist destination. We find that the accessibility by public transportation to tourist destinations with high global importance, specifically Christian-religious sites is relatively low. In the final part of the paper we propose a number of explanations for that.
\end{abstract}

\section{Keywords}

Accessibility, Cities, Spatial Planning, GIS, Urban Transportation

\section{Introduction}

Jerusalem is not a particularly large city. Yet it is world renown as the holy city to the three large monotheistic religions. Jerusalem's fame thus largely stems from the holy sites. Several additional sites, such as the Yad Vashem holocaust 
memorial, add to its fame. These sites, which are also the main attractions for international tourists [1], make it a city of global importance. Concurrently, Jerusalem is a functioning city, albeit a highly contested one [2] [3]. As such it struggles with day-to-day issues such as traffic [4]. This raises the question: What is the place of the tourist sites in the planning of Jerusalem's public transport system?

While Jerusalem may seem as an extreme case, it is not unique. Many cities attract large number of tourists to various widely renowned sites within them, in many cases with religious facets [5]. Public transport systems are largely designed to address the demand of local residents. Yet, tourist flows often differ from the travel patterns of local residents, both temporally and spatially [6] [7]. Thus, the extent to which public transport systems address tourists' demand can be hypothesized to be a function of the degree to which tourist destinations lie in proximity to travel nodes of local residents, and the extent to which it is modified to address the spatiality and temporality of tourist flows.

In this paper we assess the extent to which Jerusalem's public transport system provides accessibility to the sites that make the city globally renowned. To this end we first present a very brief overview of the relations between tourist travel pattern and urban public transport systems. Then we contextualize the "global" Jerusalem that most tourists seek within the fragmentized geography of Jerusalem. This is followed by a brief description of the current, highly segmented, public transport system in the city. In Section 4 the methodology used is described, followed by a description of the results-the extent to which various sites are accessible from the main tourist accommodations. In the final section these results are discussed, and several possible explanations are advanced for the seeming omission of major sites from the public transport map.

\section{Tourist Flows and Public Transport: A Brief Overview}

Cities in general and polycentric cities in particular, generate a complex set of travel patterns. Most of the attention of researchers, planners and policy makers focuses on commuting and shopping related trips. Touristic-related and leisure-related travel receives far less attention [8] [9]. Commuting and shopping related travel are largely conducted in a familiar area. In contrast, tourists, and particularly international tourists, often travel in unfamiliar environments. Tourists in such unfamiliar urban settings seek to visit various attractions in a limited amount of time and often with a limited budget [10] [11]. Hence, the compatibility of the public transport system with tourists' demands has widespread implications for tourists' visitation experience [12] [13]. For this reason, the International Association of Public Transport stated in its directive from 2003, that the public transportation sector must adapt itself to the growing needs of tourism. If transport planners ignore tourists' needs, the destination city may be perceived as a less welcoming attraction for tourists [14].

Ashworth and Tunbridge [15] suggest that over time there is an increasing 
discrepancy between the focal points of economic activity (particularly the CBD) and the historic city. As a result a discrepancy may arise between the main commuting and shopping destinations and the destinations of tourists. If the public transport system is geared mainly toward commuters' and shoppers' demand, it may not serve well the needs of tourists. This is the hypothesis we test for the case of Jerusalem.

\section{Jerusalem as a Global Tourist City: One of the Four Cities of Jerusalem}

\subsection{Land Use}

Jerusalem is the largest city in Israel with a total population of almost 850,000 inhabitants, of which $63 \%$ are Jewish and approximately $37 \%$ are Arabs [16]. Jerusalem is hotly contested along national, ethnic and religious lines [2] [4]. Hence, political, demographic, social and religious contradictions are salient in the city's configuration [17]. Jerusalem is holy to the three main monotheistic religions, hosting many of the holiest sites for these religions. Hence Jerusalem is, from a touristic perspective, a potential world city. The number of incoming tourists to Jerusalem has generally risen, though it suffered from significant downturns after outbreaks of violence, such as the second intifada [1].

Jerusalem is highly segmented. It is actually comprised of four different "cities": Jewish-Zionist city; Palestinian city; Jewish ultra-orthodox city and the global-tourist city. The populations of the first three "cities" have a distinctive largely segregated spatial distribution within the municipal area of Jerusalem (see Figure 1). The Arab (Palestinian) population accounts for about $35 \%$ of the population within Jerusalem's municipal boundaries. Palestinians mostly reside in separate neighborhoods, located mainly on the east side of Jerusalem (i.e. East-Jerusalem neighborhoods). The Jewish Ultra-Orthodox accounts for about $30 \%$ of Jerusalem's population. This group is a closed and very traditional society, living in nucleated-separate neighborhoods in order to minimize interactions with other groups of population. The Jewish-Zionist population, which includes both religious and secular Jews, accounts today for about $35 \%$ of the overall population of Jerusalem. Jewish Zionists are more scattered in space, but rarely reside in neighborhoods of the ultra-orthodox or Palestinians.

As can be seen in Figure 1 tourist lodgings follow a different pattern [18]. Many of the hotels ${ }^{1}$ and hostels are located in proximity to the old city and the city center. But, there are various hostels and hotels located wider afield, that largely cater to organized groups [20].

The four cities of Jerusalem are not only segmented residentially. Each "city" has its own "city-center" as well as several sub-centers, and hence each "city" has a different travel patterns-differentiated both spatially and temporally. The three "city-centers" of Jewish-Zionists, Palestinians and Jewish ultra-orthodox population

${ }^{1}$ According to the Incoming tourism survey: 2015 Annual report, 70\% of tourists in Jerusalem stayed at hotels [19] Israel Ministry of Tourism. Incoming tourism survey: 2015 half year report 2016 22/03/2017; Available from: https://info.goisrael.com/en/incoming-tourism-survey-2015-pdf. 


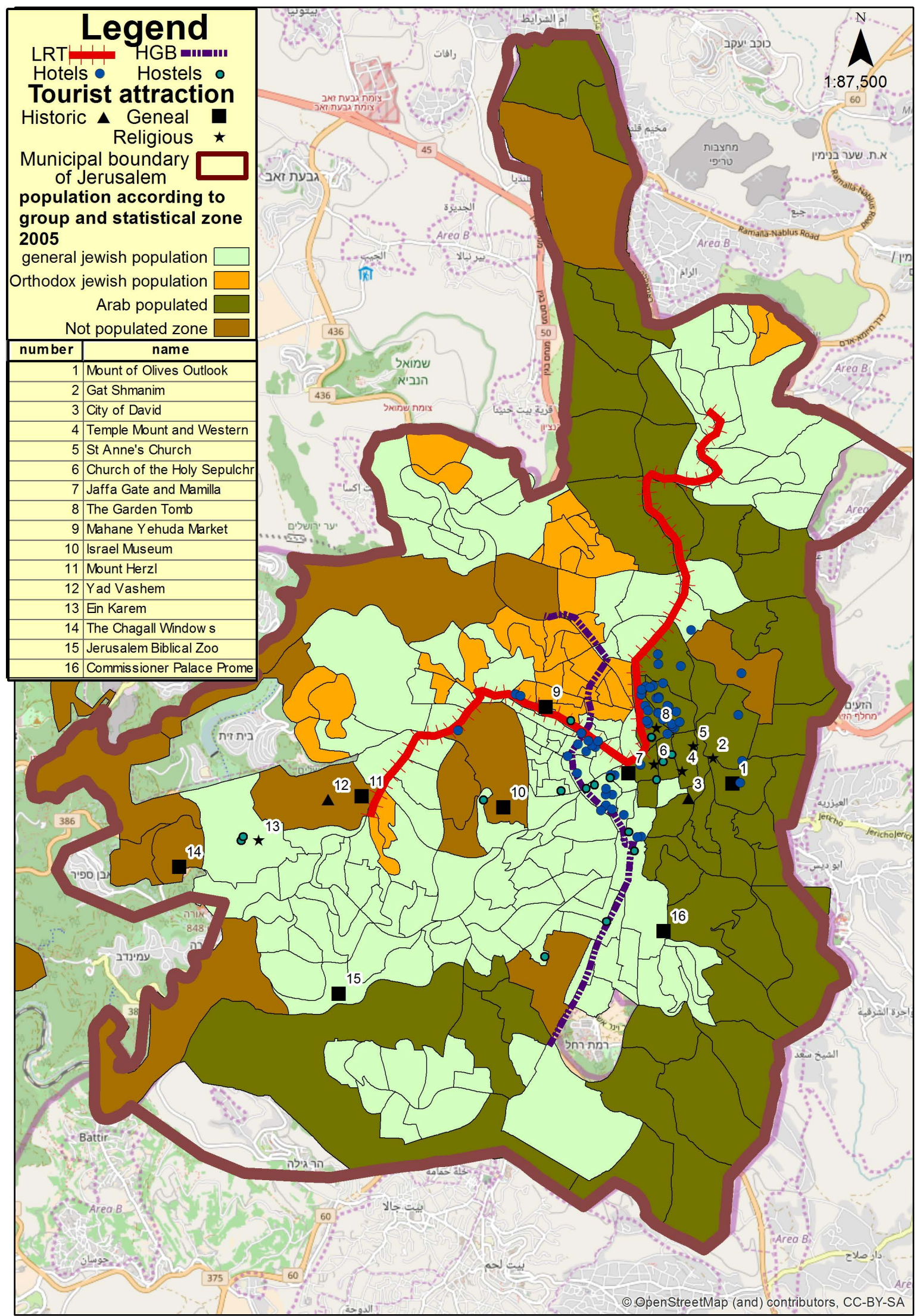

Figure 1. Municipal area of Jerusalem: Tourist destinations, hotels/hostels, population according to group and statistical zone. 
are located within walking distance from each other, but each is largely frequented by a different group. The centers of Palestinian and Jewish ultra-orthodox activities are relatively stable. However, the Jewish-Zionists center has declined significantly over the years, as its functional elements, such as the business, government offices and commercial activities, moved out of the core of Jerusalem. As a result there are several sub-centers located in the outskirts of the city. The tourists have a less distinct center. Actually many of the main sights and attractions are located outside the commercial centers, mainly in the old city and its vicinity (see Figure 1).

\subsection{Public Transportation for the Four Cities of Jerusalem}

The public transportation system in Jerusalem is comprised of three partially overlapping public bus systems, representing the sectoral segmentation of the population, and one line of Light Rail Transit (LRT). The main bus system that provides services to most of the city is operated by Egged. The Egged cooperative is the largest transportation operator in Israel. In Jerusalem it operates 69 bus routes that are authorized by the Ministry of Transportation and receives state subsidies. The bus system used by the Ultra-Orthodox Jewish population includes lines on which there is illegal but de-facto segregation of men and women. In those buses men enter and exit through the front door and sit in the front of the bus, while women enter and exit through the back door and sit at the back. [21] [22]. The third bus service is the East Jerusalem bus system. This bus system is comprised of 17 different private operators that formed an association in 2002 under common livery and coordination [23] (i.e. unified logo and agreed timetable) with no common ticketing system. This system is confined to the Palestinian neighborhoods of Jerusalem and the surrounding Palestinian metropolitan area [24].

The main shared component of the public transportation system is the LRT which currently comprises a single line stretching from the north-east to the south west of the city, passing near the old city (Figure 1). Moreover, in addition to connecting peripheral neighborhoods with the city center, it connects the three segmented "cities" of Jerusalem. Here we emphasize the LRT since it is the most visible transport artery in the city, especially for foreign tourists. Thus the LRT offers an easier way finding alternative for tourists in comparison to the complex bus network. This paper attempts to understand to what extent does Jerusalem's public transportation system offer accessibility to the destinations that make it into a tourist world city.

\subsection{Tourists and Tourism Sites in Jerusalem}

This paper examines the compatibility of the existing public transportation system to touristic purposes. Therefore we focus on tourists that use public transportation services. Hence, according to Cohen's [25] [26] classification, the study differs between individual tourists and organized mass tourists who are confined to an "environmental bubble" that enables them by guided all-inclusive package 
tours to travel without the service of local public transportation system [27]. Specifically, this paper focuses on tourists who are not bound to a group, and who use the local public transportation system, whether they are individual mass tourists, explorers or drifters according to Cohen's [25] [26] definitions. Overall approximately $80 \%$ of the tourists entering Israel visit Jerusalem, amounting to 1.3 to 2.4 million tourists per year since 2006. In 2015, the average number of nights in Jerusalem for non-domestic tourists was 3.4 nights, similar to the average number in 2013 and 2014, but higher than the 3.3 nights average length of stay recorded between 2007 and 2011 [28]. According to the incoming tourism survey conducted for the Israel ministry of tourism, $68 \%$ of the independent travelers, visit Jerusalem [19].

Most destinations in Jerusalem are of historic importance; many, but not all, are important for religious reasons. Several of them are of importance to more than one religion. In general, there is a distinct spatial configuration of the tourist destinations in Jerusalem. The Old City is the main tourist destination, in which many religious sites are located within walking distance (yet, topography hinders comfortable walking). Eastern Jerusalem continues to function largely as a pilgrimage and historic tourist node, as many of the Christiane religious sites are situated within it. Western Jerusalem is characterized by secular tourist sites, such as the Yad Vashem (the holocaust memorial), the Israel Museum, the Biblical zoo and Mahane Yaehuda market, as well as some religious sites (mainly Ein Karem, birthplace of John the Baptist).

The tourist sites in Jerusalem may be defined according to two criteria: type and affinity. The type of attraction is defined as religious, historic or general. Affinity relates to the population who has a direct relationship with the place. For example, the Church of the Holy Sepulcher is a religious site. It is sacred to Christians; hence it is defined as a Christian holy site. This does not mean that a specific tourist site attracts only those with a direct affinity; in most cases it attracts all types of tourists. Table 1 categorizes the main tourist destination in Jerusalem.

Table 1 also describes the available public transport (PT) services and walking distance from the closest stations to each tourist site. Where bus is the only available mode of PT, the level of service (LOS) is also a function of the frequency of service as the frequencies differ among lines, an issue we discuss further on.

\section{Methodology}

Accessibility measures the ease with which activities can be reached from a location using a particular transport system [29] [30] [31] [32]. Accessibility is determined both by patterns of land use and by the transportation system [33] [34]. Yet, it is considered as a slippery construct that is often misunderstood and poorly measured [35]. Here we adopt the generalized formulation of accessibility as suggested by Ingram [36], Koenig (1980) and others: 
Table 1. Categorizing tourist destinations in Jerusalem.

\begin{tabular}{|c|c|c|c|c|c|}
\hline$\#$ & Name & Type & Affinity & $\begin{array}{c}\text { PT } \\
\text { service }\end{array}$ & $\begin{array}{l}\text { Walking distance } \\
\text { from station }(\mathrm{m})\end{array}$ \\
\hline 1 & $\begin{array}{c}\text { Mount of } \\
\text { Olives Outlook }\end{array}$ & General, Religious & Christian, Jewish & Bus & 423 \\
\hline 2 & Gethsemane & Religious & Christian & Bus & 179 \\
\hline 3 & City of David & Historic & Jewish & Bus & 25 \\
\hline 4 & $\begin{array}{l}\text { Temple Mount and } \\
\text { Western Wall }\end{array}$ & Religious & Jewish, Muslim & Bus & 270 \\
\hline 5 & $\begin{array}{c}\text { Via Dolorosa } \\
\text { (St Anne's Church) }\end{array}$ & Religious & Christian & Bus & 255 \\
\hline 6 & $\begin{array}{l}\text { Church of the Holy } \\
\text { Sepulcher }\end{array}$ & Religious & Christian & Bus & 252 \\
\hline \multirow[t]{2}{*}{7} & Jaffa Gate & \multirow[t]{2}{*}{ General } & \multirow[t]{2}{*}{ All } & LRT & 228 \\
\hline & & & & Bus & 117 \\
\hline \multirow[t]{2}{*}{8} & The Garden Tomb & \multirow[t]{2}{*}{ Religious } & \multirow[t]{2}{*}{ Christian } & LRT & 300 \\
\hline & & & & Bus & 228 \\
\hline \multirow{2}{*}{9} & Mahane & \multirow{2}{*}{ General } & \multirow{2}{*}{ secular } & LRT & 140 \\
\hline & Yehuda Market & & & Bus & 78 \\
\hline 10 & Israel Museum & General & secular & Bus & 64 \\
\hline 11 & Mount Herzl & General & secular & LRT & 261 \\
\hline 12 & Yad Vashem & Historic & Jewish & LRT & 500 \\
\hline 13 & Ein Karem & Religious, General & Christian & Bus & 101 \\
\hline 14 & The Chagall Windows & General & All & Bus & 48 \\
\hline 15 & Jerusalem Biblical Zoo & General & secular & Bus & 62 \\
\hline 16 & $\begin{array}{c}\text { Commissioner } \\
\text { Palace Promenade }\end{array}$ & General & All & Bus & 84 \\
\hline
\end{tabular}

$$
A_{i}=\sum_{j} O_{j} f\left(C_{i j}\right)
$$

where $A_{i}$ is the accessibility to zone $i$ from the relevant origins $\left(O_{i}\right)$ in the area. The Impedance function, $f\left(C_{i j}\right)$, certifies that accessibility increases as the cost of travel $\left(C_{i j}\right)$ between the two locations decreases. Accessibility studies explored different methods to estimate the travel cost function [34] [37] [38] [39] [40] [41]. The current study estimates accessibility, by combing a GIS (Geographical information systems) application to the measurement of accessibility of public transport.

This study uses Least Cost Modeling (LCM) to measure the effective distance, rather than the Euclidian distance, to different endpoints. The objective of LCM is to assess the least costly route to reach a destination. However, instead of calculating the actual distance from one origin to a destination, the cost distance tools 
determine the shortest weighted distance or accumulated travel cost. As a result distance is measured in cost units, rather than geographic units, and can be viewed as reverse accessibly units. Therefore, LCM actually offers an accessibility measure that is relatively easy to interpret [42] [43].

Least cost modelling is a well-known analysis tool, mainly used as connectivity measure by ecologists. LCM has been widely used in research that aims to monitor wildlife movements and to plan natural systems to overcome habitat fragmentation [43]. Yet, while LCM is receiving growing attention in applied landand species-management research, it has received little attention in urban and transportation research. As LCM improves the ability to address connectivity issues by modelling the effective distance, rather than the Euclidian distance [44], it has been suggested that LCM have a great untapped potential for addressing a variety of problems [45]. However, this potential has not been utilized yet in urban transportation settings as is done here.

A GIS desktop application is the platform for conducting least-cost analyses. Typically, a resistance surface in raster format is the input to the least-cost modeling. This resistance layer serves as a cost surface, which reveals how the surface facilitates or hinders movement [46] [47]. Subsequently, GIS layers in polygon or grid format are weighted according to the expected resistance encountered by an individual when moving across the surface, and linear features are then merged with the weighted resistance surface. The outcome of the analysis is a "cost" layer around a "test" point. The cost units represents the distance to the "test" point measured as the lowest cost for travel over the resistance layer between two points [17] [43] [48].

For the purpose of this study, we use LCM to estimate the ability of individuals to reach activities or destinations by means of relevant transport modes. Here, the individuals are tourists; the origins are hotels/hostels and tourist destinations are the test points. The transport mode examined is public transportation. The resistance surface is based according to the infrastructure and features of mode of travel available (i.e. buses, LRT).

Table 2 specifies the resistance level used in this study. The resistance level for tourists was set using public transport service. For determining the cost level of each mode of transport, the characteristics of each mode was first configured

Table 2. The resistance levels.

\begin{tabular}{cccc}
\hline Mode of transport & $\begin{array}{c}\text { Frequency } \\
\text { (minutes) }\end{array}$ & Explanation & Cost level \\
\hline LRT & $0-5$ & Highest Visibility, Right of way High LOS & 50 \\
HGB & $0-10$ & Right of Way & 3000 \\
Buses (3) & $0-15$ & Lower Visibility & 6000 \\
Buses (2) & $15-30$ & $\begin{array}{c}\text { in Comparison } \\
\text { to LRT }\end{array}$ & 9000 \\
Buses (1) & $30-60$ & & 12,000 \\
Walking & & & 22,000 \\
\hline
\end{tabular}


(frequency and availability, visibility, right of way). LRT received the basic cost level and according to it, the other modes of transport were estimated [17]. The cost levels of all other PT services are thus estimated in essence as the difference between their LOS and that of the LRT. Sensitivity tests were conducted to verify the differences between modes and to determine the final assignment of the cost levels. LRT receives the lowest cost value, since it has a separate right of way and frequent service and hence provides the highest level of service. Moreover, it is highly visible and easy to orient by. In general, tourists tend to be more comfortable riding light rail (or subways, where possible) systems because they are linear and clearly demarcated. Buses, on the other hand, tend to weave in and out of neighborhoods and do not have clearly demarcated exit points. Therefore, the cost level of bus service, whose network is less obvious, was determined according to the frequency of the bus service. High Grade Buses (HGB) service in Jerusalem does not operate exclusively on a separate right of way, but are managed as high-quality lines that use dedicated lanes and thus are slightly faster and their routes are clearer. Therefore, the lines that are designated as HGB have a lower cost level then other buses. Walking receives the highest cost value. Hence, the longer the walking distances to or from public transport, the less accessible the site.

Data was obtained from the Ministry of Transport as data in a General Transit Feed Specifications (GTFS). The data was applied into the GIS software and, where needed, was partially manually digitized. The vector format of the map of Jerusalem, according to its statistical zones, was the basis for creating accessibility maps to the various sites using public transport. Next, the maps were converted to a raster format to enable the use of the cost weighted distance function.

The study consists of two phases: 1) Creating accessibility maps; 2) Calculating the Cumulative Effective Distance (CED). First a resistance level is created in a raster format. Then, GIS layers in polygon or grid format are weighted according to the expected resistance encountered when moving across the surface. The outcome of the analysis is a layer in relation to a specific "test" point (a single touristic site for each map). In this study, the locations of sixteen tourist destinations were marked as test points (see Figures 2(a)-(d) for four examples). The hotels and hostels in the Jerusalem municipality area were defined as origins. Each map produced, revealed the Effective Distance (ED) in cost units to each touristic destination ( $i)$, from all hotels and hostels in the municipal area in Jerusalem $(j)$. Subsequently, in the second phase, this enabled the calculation of the Cumulative Effective Distance (CED) of the relevant destinations, and thus to assess the accessibility to each touristic destination:

$$
\mathrm{CED}_{i}=\sum_{j=1}^{n} \mathrm{ED}_{i j}
$$

In the next section, we demonstrate and describe four maps of four touristic sites, and explain the visualization of accessibility as it appears in each map. Afterwards, we compare accessibly calculations for all touristic destinations and discuss them in relation to the complex public transport in Jerusalem and connect it back to the four "cities" of Jerusalem. 


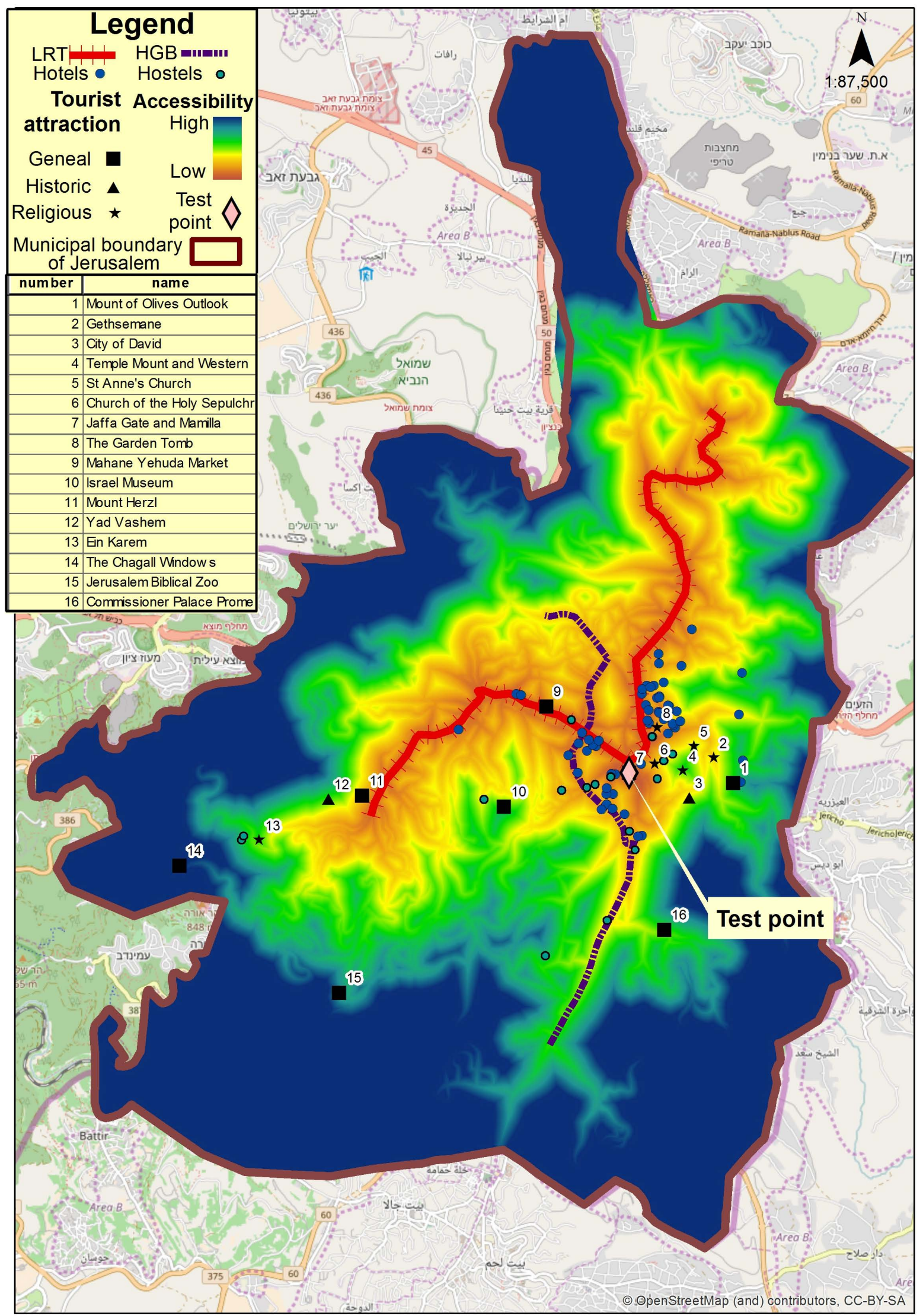

(a) 


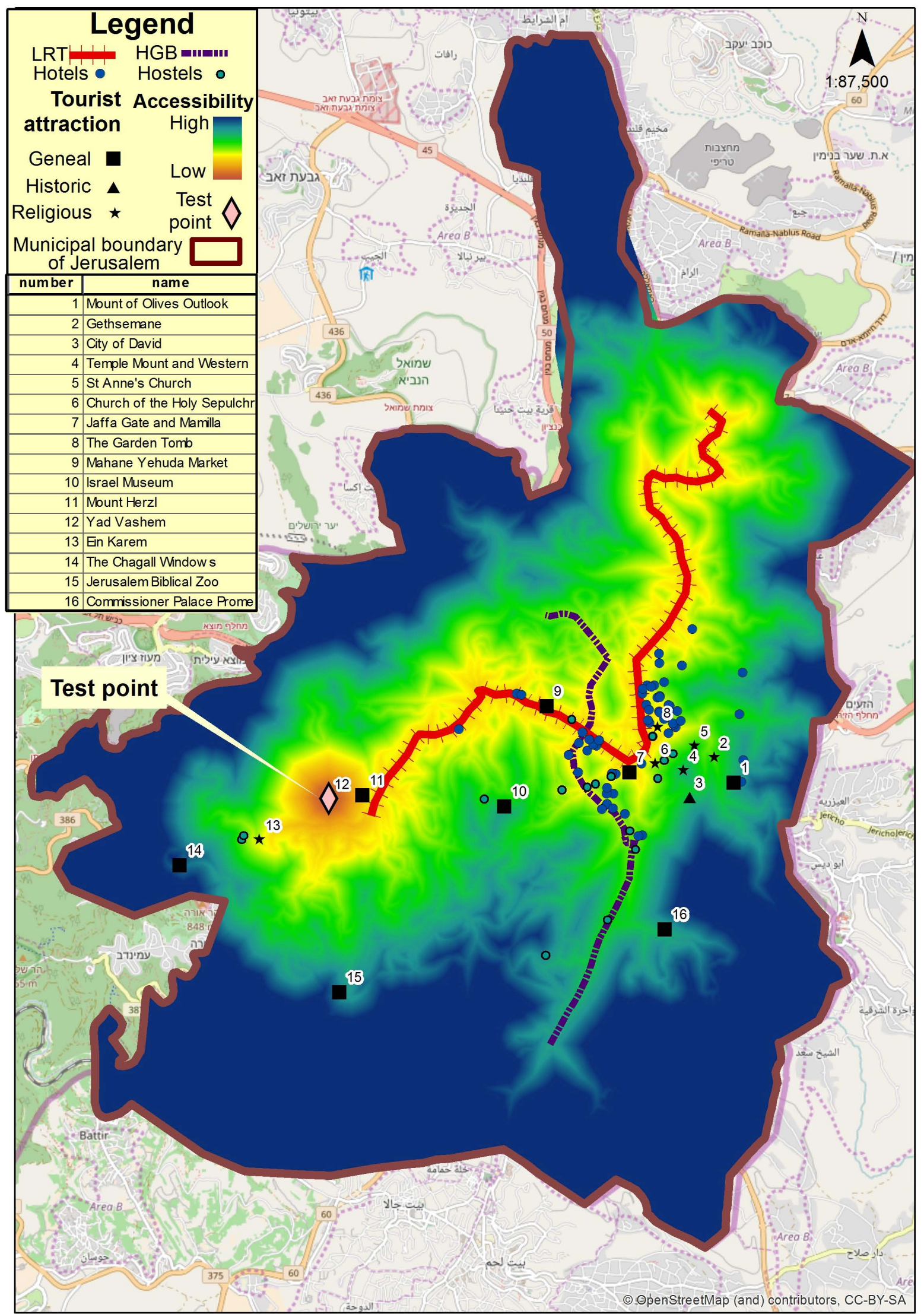

(b) 


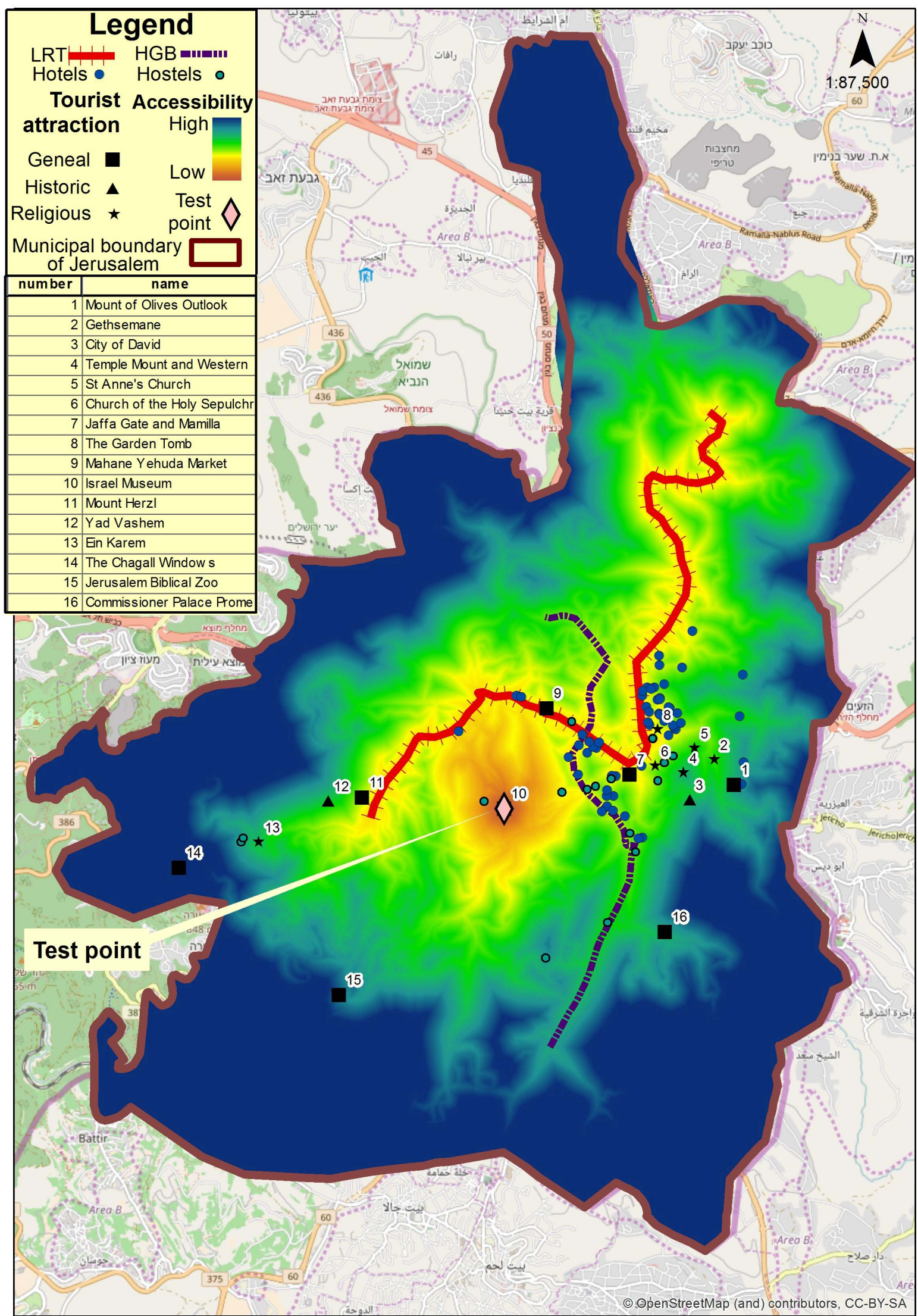

(c) 


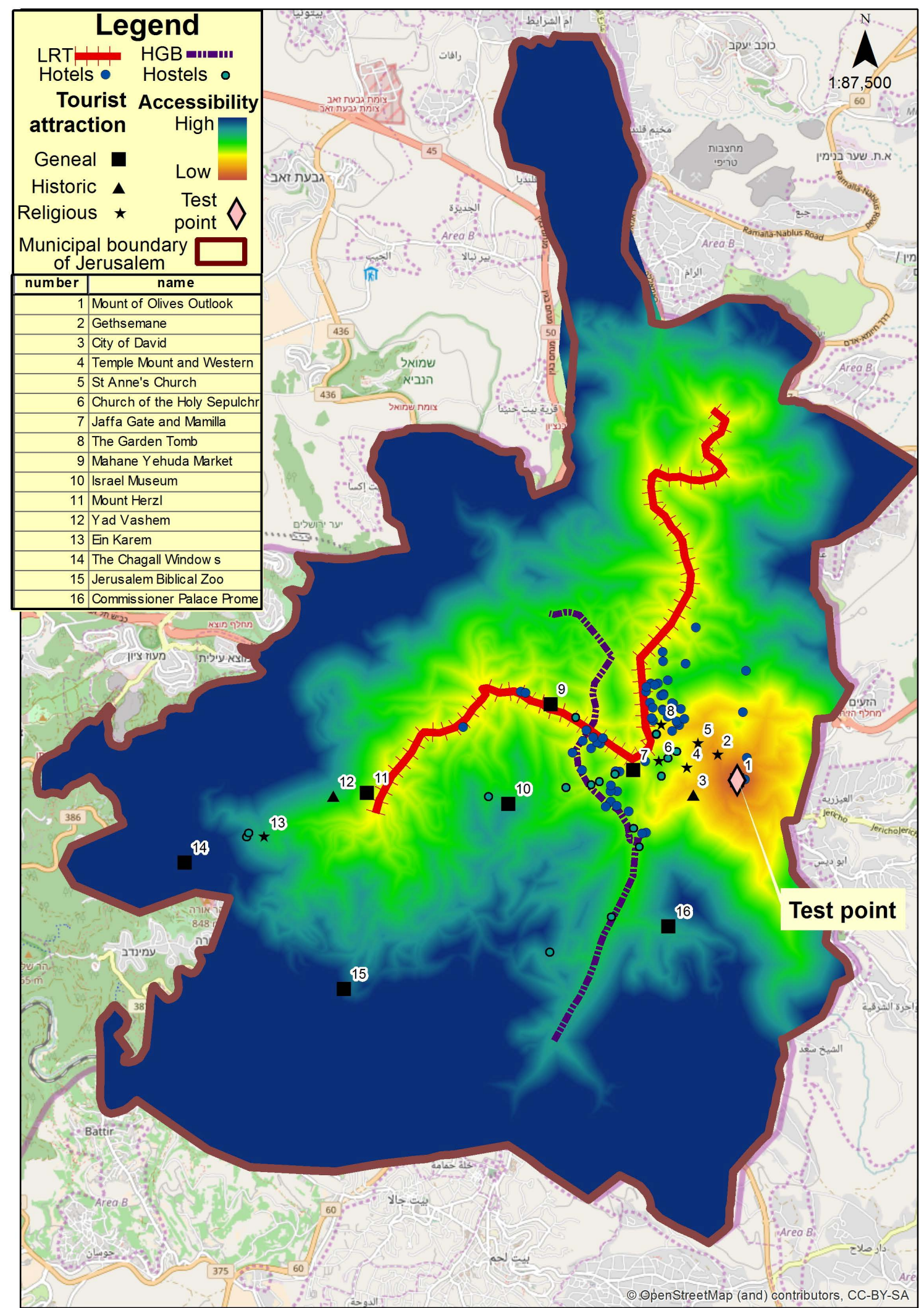

(d)

Figure 2. Representative accessibility maps to selected sites. (a) Jaffa gate and Mamilla; (b) Yad Vashem; (c) Israel museum; (d) Gethsemane. 


\section{Results}

To demonstrate the output of the LCM based analysis we present in this section the LCM output maps for Gethsemane (a religious Christian site), Yad Vashem (an largely Jewish memorial site), The Israel Museum (general secular site) and Jaffa gate and Mamilla shopping center (a general site for all types of tourists). The latter destination also serves as a gate to various Christian, Jewish and Muslim sites located inside the Old city (mostly David's Citadel and the city museum within it, and the old city's markets). Similar maps were prepared for all the destinations identified in Table 1.

The Jaffa gate and Mamilla shopping center map (Figure 2(a)) represents highly accessible sites. It is located next to the LRT, as well as regular bus services. Due to the short distance to many hotels and hostels, as well as its proximity to various modes of public transportation, it is considered as the most accessible tourist destination in the city. In contrast to the high accessibility of Jaffa gate from all directions, Yad Vashem (Figure 2(b)), located in western Jerusalem is accessible only from one direction. It is situated close, but not in direct proximity, to the LRT station on Mount Herzl. While it enjoys the accessibility offered by the LRT, Yad Vashem is relatively far from most hotels and hostels in Jerusalem, and requires a 500 meters walk from the LRT station. This increases significantly the CED of Yad Vashem relative to other destinations that are located along the LRT route.

The Israel museum (Figure 2(c)) is also located in the western area of Jerusalem. It is closer to the various hotels and hostels that Yad Vashem in Euclidean distance. However, as it is further from the LRT with only one hostel within walking distance it can only be reached by regular bus services from all other origins. Hence, the CED of the Israel Museum is almost the same as Yad Vashem.

Gethsemane (i.e. Church of all Nations) is located on the bottom of Mount of Olives. It is within a short walking distance of The Russian Orthodox Church of Maria Magdalene and Dominus Flevit (a Roman Catholic Church). According to the ministry of tourism $52 \%$ of incoming tourists in Jerusalem visit these churches [49]. Gethsemane (Figure 2(d)) is also an example of a destination served only by buses. In this case it is important to assess not only the CED, but also to understand the type of bus line that serves this destination. This destination is mostly served by Kavey Mehadrin (routes from ultra-orthodox neighborhoods to the western wall) and east Jerusalem lines. These two services are geared to the population segments they serve (the Ultra-Orthodox and Palestinian population, respectively). Hence, they are hardly visible to tourists. Thus the likelihood that tourists will utilize these services is low.

Figure 3 presents the results of the calculation of cumulative effective distance to all tourist sites studied, ordered by CED. For each tourist destination, the CED from all hotels and hostels was calculated. As can be seen in Figure 3, Jaffa gate (and Mamilla), the Garden Tomb and Mahane Yehuda market, are the most 


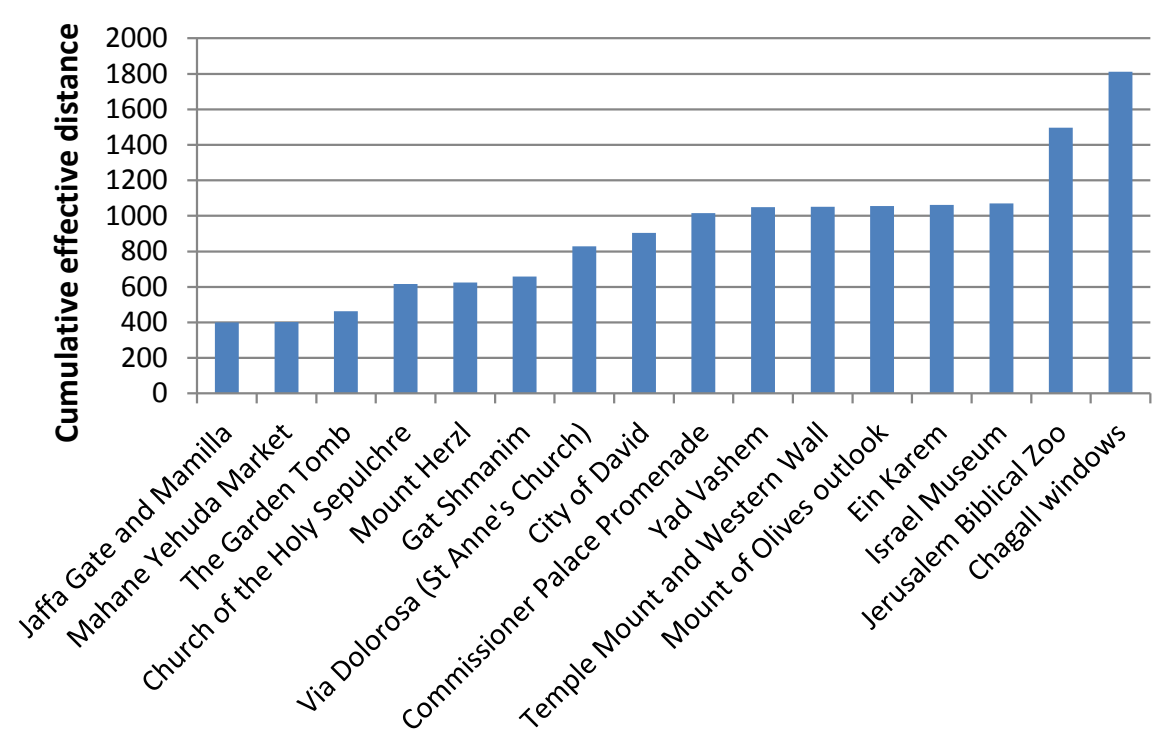

Figure 3. Cumulative effective distance to tourism sites (full bus system).

accessible destinations in Jerusalem, mainly due to their central location and proximity to the LRT line. At the other extreme, the less accessible locations in Jerusalem are the Biblical Zoo, Mount of Olives outlook and Chagall windows. While the Chagall windows and Biblical zoo are clearly not religious-oriented, the Mount of Olives outlook is in close proximity to several churches and holy places (most notably the Chapel of the Ascension and Church of the Pater Noster).

The high CED of these sites is a function of their distant location, the distance from the LRT and the low bus LOS. Between these two extremes there are several sites with high-medium accessibility. These include Mount Herzl, Gethsemane, Via Dolorosa and the Church of the Holy Sepulcher. However, the explanation for the level of accessibility is different for each site. For example, the Church of the Holy Sepulchre is not far from two LRT stations, but is not directly proximate to them, and hence requires a longer walk from them. Mount Herzl is located in direct proximity to LRT station, but, it is relatively further (in kilometers) from hotels and hostels. The majority of destinations analyzed in this research are part of the low-medium accessibility group: Commissioner Palace Promenade, Yad Vashem, Ein Karem, City of David, Temple Mount and Western Wall, Israel Museum. Several of these destinations are located in the western area of Jerusalem, reached mainly by regular bus service. It is notable that the City of David, as well as the Western Wall, that have a strong Jewish affiliation, also suffer from low accessibility, while many of the Christian sites enjoy better accessibility—a topic we discuss further on.

However, as noted above the bus system in Jerusalem is not a unitary service. As the Ultra-Orthodox and Palestinian services are largely opaque to most tourists, including all the bus lines in our calculation may create a bias in terms of their availability to tourists. In reality only the Egged services information is available to tourists. Therefore, an additional calculation of CED was carried out, 
focusing on Egged services and LRT. While the new calculation does not ignore the presence of Kavey Mehadrin in the city, it reduces their visibility by increasing the cost level. In other words, such bus lines receive a lower visibility rate. The results of the new calculation are presented in Figure 4. The percentage of change (the black dots relating to the right hand scale) represent the implications of the lower visibility of the available bus service for tourist. The black dots show that several destinations were substantially (adversely) affected. Once the LRT and Egged services are calculated as being the most visible to tourists the CED of destinations such as the City of David, Jaffa Gate and Mamilla, Gethsemane and Commissioner Palace Promenade, rises by more than 30\% (and hence their accessibility diminishes). These results demonstrate the problems tourists face when attempting to use public transportation in Jerusalem as the main mode of travel. Moreover, the difference between the two calculations of CED highlights the gap between how urban and transport planners perceive the level of service of the public transportation in Jerusalem and how tourists experience it.

\section{Discussion}

Two factors affect the accessibility to touristic sites by public means: the location of accommodations (mainly hotels and hostels) and the alignment of the public transport system. In Jerusalem most of the hotels catering to individual tourists can be found in proximity to the old city or along the first route of the LRT [18]. Hotels further afield largely cater to groups [20], which are not part of this study. Hence, the main factors affecting the accessibility of the various sites are their location and proximity to the public transport routes, and particularly the LRT. From a policy perspective this implies that the main factor affecting the LOS of the public transport for tourist is the alignment of the public transport system, and particularly the main highly visible lines of the LRT and to a lesser extent the HGB. The question is thus to what extent the demand of tourists affects the alignment of these lines.

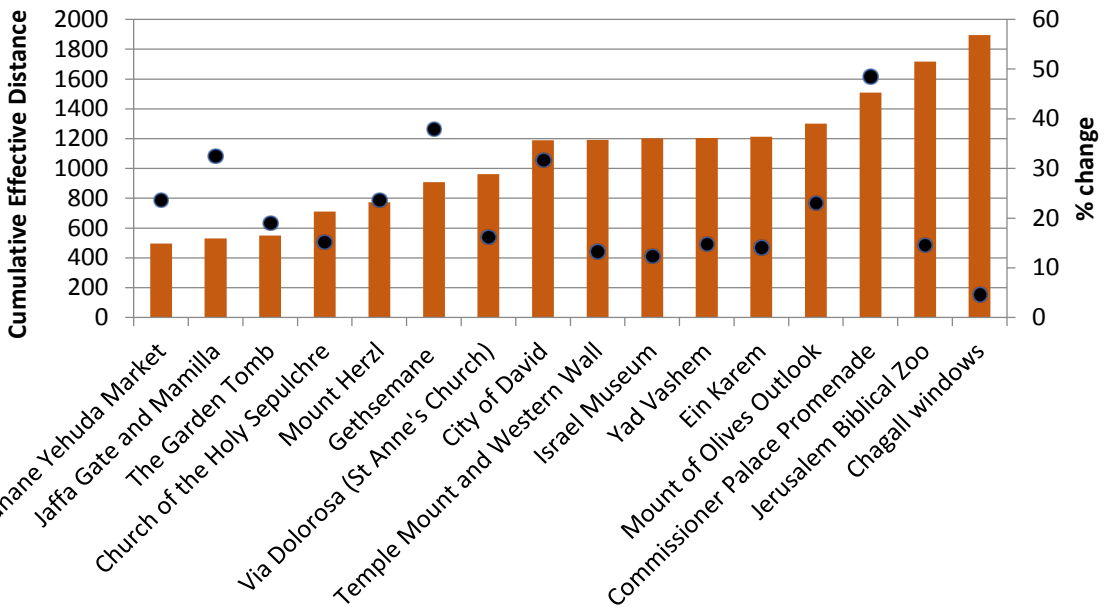

Figure 4. Cumulative effective distance with adjustment to Kavey-Mehadrin. 
The two most accessible sites identified in Figure 3 and Figure 4 Mahne Yehuda market and Jaffa Gate/Mamilla are widely frequented by Jerusalem's residents. The same is true, to a lesser extent of Mount Herzel, as the LRT station at its entrance, which is the current terminus of the LRT, is one of the major points of transfer for Jerusalemites coming from the southwestern part of the city. With the exception of the Garden Tomb, which happens to be located close the LRT and the Palestinian $\mathrm{CBD}$ and the Chagall Windows which are within the Ein Karem Hadassah Hospital, all other sites are not major nodes in the daily activity patterns of Jerusalemites, and hence the LOS to these sites tends to be lower.

The role of tourist sites in planning Jerusalem's public transport systems can be garnered also by looking at the current planned expansions of the LRT system. These include at present extensions of the existing line to Neve Yaacov neighborhood in the north, to the Ein Karem Hadassah hospital in the south west and to the two campuses of the Hebrew University (on Givaat Ram and Mount Scopus). The next two lines are planned from the southern part of the city to the northern part of the city, passing through the center, thereby largely by-passing the old city region. From a tourism perspective they will greatly improve the accessibility of the Chagall windows which are within the Ein Karem Hadassah hospital, and perhaps somewhat improve the accessibility to the Israel Museum. With these two exceptions none of these extensions will improve the accessibility of the main under-served sites analyzed herein. Moreover, also in the case of the Chagall windows and the Israel Museum the extensions of the existing line is not geared toward them, and the improved accessibility to these sites can be considered a positive externality of improvements geared to other nodes (the hospital and the university).

Seemingly, the Palestinian and Ultra-Orthodox services can provide a partial response to the lacunas in the LRT and Egged bus services. Yet, these services are largely invisible to tourists. They are very hard to find on the web in English, and do not appear on the municipal English-language sites. While the Kavey Mehadrin may well try to avoid serving tourists, as they seek to maintain the unofficial and illegal gender-separation, the Palestinian service can well serve tourists, as it does serve some of the least accessible sites such as Mount of Olives. Thus, the segmentation of the public transport services has particularly adverse effects for tourists, as the lack of coordination between these systems prevents tourists from utilizing the relative advantages of the different systems.

The picture that emerges from our analysis, as well as from the analysis of the proposed extension of the LRT system, is that public transport lines are demarcated as a function of the demand by residents. Tourists are hardly taken into account, if at all. As a result some ad-hoc services are provided by sites interested in attracting visitors. Most notably, Yad Vashem operates a shuttle service from the Mount Herzl terminus and a new shuttle has started to operate from the old train station (called first Station) to the Western Wall. While there is a single hop-on hop-off line (no. 99), its service is very infrequent, and it fails to provide an effective tourist-oriented service. Hence, the lack of tourist-oriented services, 
pointed out more than a decade ago by Israeli and Mansfeld [13], has not been improved in the interim, and major sites, which constitute the world image of Jerusalem, continue to be under-served.

\section{Conclusions}

Tourist flows do not conform to the travel patterns of Jerusalemites, both spatially and temporally. Being segmented as it is, the different segments of the Jerusalem population are served by three different bus services, as well as by the LRT. Yet, none of these provides the services that would make all the historic and religious sites with which Jerusalem's worldwide fame rests accessible to tourists. Rather, the public transport system, both existing and planned, is geared toward the needs of the three population groups that jointly are called Jerusalemites, thereby disregarding the fourth travel segment-the tourists.

There are two possible explanations to the oversight of the tourist travel segment in Jerusalem. The first is a professional oversight. Since transport planning tends to focus on peak hour travel during working days, public transport is geared toward such travel. The travel demand to tourist destinations during these peak hours is low, and hence they are not accounted for in the public transport plans. For this reason only tourist destinations that are in proximity to sites to which there is high demand in peak hours are well served.

The second explanation is political. Public transport provision has a political dimension. This is perhaps more poignant in Jerusalem then elsewhere (Shlay \& Rosen, 2015). The lack of services to tourist destinations from this perspective can be attributed to the lack of interest in serving Christian pilgrims or as the lack of power of tourism interests in the city. As the results of this study show that marginalized sites cannot be differentiated by religiosity or denomination the first option is rejected. The second option requires further study. But it can be hypothesized that the heavy reliance on groups (whether pilgrims or not) and on high-end tourism, and the fragmented nature of the tourism industry in Jerusalem, result in the relative disinterest of tourism interests in the public transport field, and hence in the absence of a voice for the individual international tourist in the forums where public transport decisions are made. While a full analysis of both explanations is beyond the scope of this paper, it seems that both of them combined to explain the oversight of the tourist sector in the provision of public transport services in Jerusalem.

Still, several improvements in the LOS provided to independent tourists can be derived from this study. The most obvious is to make better utilization of the Palestinian bus system, which provides services to some of the under-served sites in east Jerusalem, such as Mount of Olives and Gethsemane. To this end the routes and schedules have to be displayed in English, and an English-language website that includes all these services should be set. A second, complementary, step is to provide integrated ticketing to all bus companies and the LRT available to tourists for various lengths of stay. A third, costlier option is to provide tour- 
ist-oriented specialized services such as frequent hop-on hop-off services, particularly in peak tourist season. Such a service, suggested long ago by Israeli and Mansfeld (2003), may be difficult to sustain due to the variances in tourist flows, and the political tensions in the city. A somewhat cheaper alternative may be shuttle services to the main LRT stations, such as operated by Yad Vashem. A prerequisite to the planning of such services should be a survey of independent tourists regarding their travel patterns and needs. At present such tourists often have to do with other alternatives (such as taxis, or one-day tours), that are often more expensive than the PT. But the utilization of these options may be due to the lack of better PT services, and hence a demand analysis is warranted.

As none of the PT improvement provisions suggested above is likely to be advanced by the transportation authorities, due to their focus on "regular" services to Jerusalemites, there will be a need to find someone who will seek to improve the services to tourists. Such a "champion" can be the Ministry or national company for tourism, the municipality, or a body created for this purpose at the behest of local tourism interests by either the ministry of the municipality. Thus, it seems that the main obstacle to the advancement of tourist-responsive public transport services in Jerusalem is the lack of an institutional actor who will make this a priority.

While this paper focuses on Jerusalem, the general question of how should tourists be served when the main tourist sites are not in proximity to the main nodes used daily by the local population requires attention. To this end the methodology used here, whereby CED was differentiated from the Euclidian distances by using LCM, and the origins and destinations were specified for the international individual tourists, can be used elsewhere. Clearly, such analyses can then be utilized to plan for tourist-oriented public transport systems (such as extensive hop-on hop-off buses). The question is whether the municipal authorities have the incentive to do so. In the highly segmented and highly contested Jerusalem scene tourist interests do not receive wide attention, and do not have sufficient political clout. In places where tourism has a greater role, or tourism-related interests have greater economic and political clout such services can be expected to be provided. However, an examination of this hypothesis remains for future studies.

\section{References}

[1] Cohen-Hattab, K. and Shoval, N. (2015) Tourism, Religion and Pilgrimage in Jerusalem. Routledge, London and New York.

[2] Yiftachel, O. (2016) The Aleph-Jerusalem as Critical Learning. City, 20, 483-494. https://doi.org/10.1080/13604813.2016.1166702

[3] Shlay, A.B. and Rosen, G. (2015) Jerusalem: The Spatial Politics of a Divided Metropolis. John Wiley \& Sons.

[4] Ahimeir, O. and Bar-Siman-Tov, Y. (2008) 40 Shana b’Yerushalayim (40 Years in Jerusalem). Jerusalem Institute for Israel Studies, Jerusalem.

[5] Nolan, M.L. and Nolan, S. (1992) Christian Pilgrimage in Modern Western Europe. Haworth Press. 
[6] Guiver, J. and Stanford, D. (2014) Why Destination Visitor Travel Planning Falls between the Cracks. Journal of Destination Marketing \& Management, 3, 140-151. https://doi.org/10.1016/j.jdmm.2013.11.005

[7] Page, S. (2005) Transport and Tourism. Pearson Education.

[8] Lew, A. and McKercher, B. (2006) Modeling Tourist Movement: A Local Destination Analysis. Annals of Tourism Research, 33, 403-423.

https://doi.org/10.1016/j.annals.2005.12.002

[9] Hall, D.R. (1999) Conceptualising Tourism Transport: Inequality and Externality Issues. Journal of Transport Geography, 7, 181-188. https://doi.org/10.1016/S0966-6923(99)00001-0

[10] Hall, C.M. and Page, S.J. (2002) Managing Urban Tourism: Environment, Place and Space. Routledge, London.

[11] Stein, K. (2012) Time Off: The Social Experience of Time on Vacation. Qualitative Sociology, 35, 335-353. https://doi.org/10.1007/s11133-012-9228-2

[12] Khadaroo, J. and Seetanah, B. (2007) Transport Infrastructure and Tourism Development. Annals of Tourism Research, 34, 1021-1032. https://doi.org/10.1016/j.annals.2007.05.010

[13] Israeli, Y. and Mansfeld, Y. (2003) Transportation Accessibility to and within Tourist Attractions in the Old City of Jerusalem. Tourism Geographies, 5, 461-481. https://doi.org/10.1080/1461668032000129173

[14] Prideaux, B. (2000) The Role of the Transport System in Destination Development. Tourism Management, 21, 53-63. https://doi.org/10.1016/S0261-5177(99)00079-5

[15] Ashworth, G.J. and Tunbridge, J.E. (2000) The Tourist-Historic City. Routledge.

[16] Choshen, M., et al. (2016) Jerusalem Statistical Yearbook for 2016. http://en.jerusaleminstitute.org.il/?cmd=statistic.544

[17] Rotem-Mindali, O. (2012) Retail Fragmentation vs. Urban Livability: Applying Ecological Methods in Urban Geography Research. Applied Geography, 35, 292-299. https://doi.org/10.1016/j.apgeog.2012.08.003

[18] Shoval, N. and Cohen-Hattab, K. (2001) Urban Hotel Development Patterns in the Face of Political Shifts. Annals of Tourism Research, 28, 908-925. https://doi.org/10.1016/S0160-7383(00)00083-9

[19] Israel Ministry of Tourism (2015) Incoming Tourism Survey: 2015 Half Year Report.

http://goisrael.com/GOVheb1/Ministry\%20of\%20Tourism/Statistics/Documents/In coming_Tourism_Survey_2015.pdf

[20] Shoval, N. (2006) The Geography of Hotels in Cities: An Empirical Validation of a Forgotten Model. Tourism Geographies, 8, 56-75. https://doi.org/10.1080/14616680500392499

[21] Feldheim, M. (2013) Balancing Women's Rights and Religious Rights: The Issue of Bus Segregation. Shofar: An Interdisciplinary Journal of Jewish Studies, 31, 73-94. https://doi.org/10.1353/sho.2013.0013

[22] Triger, Z. (2013) The Self-Defeating Nature of Modesty-Based Gender Segregation. Israel Studies, 18, 19-28. https://doi.org/10.2979/israelstudies.18.3.19

[23] Finn, B. and Mulley, C. (2011) Urban Bus Services in Developing Countries and Countries in Transition: A Framework for Regulatory and Institutional Developments. Journal of Public Transportation, 14, 5.

https://doi.org/10.5038/2375-0901.14.4.5 
[24] Romann, M. and Weingrod, A. (2014) Living Together Separately: Arabs and Jews in Contemporary Jerusalem. Princeton University Press.

[25] Cohen, E. (1979) Rethinking the Sociology of Tourism. Annals of Tourism Research, 6, 18-35. https://doi.org/10.1016/0160-7383(79)90092-6

[26] Cohen, E. (1972) Toward a Sociology of International Tourism. Social Research, 164-182.

[27] Basala, S.L. and Klenosky, D.B. (2001) Travel-Style Preferences for Visiting a Novel Destination: A Conjoint Investigation across the Novelty-Familiarity Continuum. Journal of Travel Research, 40, 172-182. https://doi.org/10.1177/004728750104000208

[28] The Jerusalem Institute for Israel Studies Jerusalem (2016) Figures and Trends: Data to Mark Jerusalem Day. 5776.

[29] Wachs, M. and Kumagai, T.G. (1973) Physical Accessibility as a Social Indicator. Socio-Economic Planning Sciences, 7, 437-456. https://doi.org/10.1016/0038-0121(73)90041-4

[30] Song, S. (1996) Some Tests of Alternative Accessibility Measures: A Population Density Approach. Land Economics, 474-482. https://doi.org/10.2307/3146910

[31] Koenig, J.-G. (1980) Indicators of Urban Accessibility: Theory and Application. Transportation, 9, 145-172. https://doi.org/10.1007/BF00167128

[32] Dalvi, M.Q. (1978) Behavioural Modelling, Accessibility, Mobility and Need: Concepts and Measurement. Behavioural Travel Modelling, 639-653.

[33] Handy, S.L. and Niemeier, D.A. (1997) Measuring Accessibility: An Exploration of Issues and Alternatives. Environment and Planning A, 29, 1175-1194. https://doi.org/10.1068/a291175

[34] Ford, A.C., et al. (2015) Transport Accessibility Analysis using GIS: Assessing Sustainable Transport in London. ISPRS International Journal of Geo-Information, 4, 124-149. https://doi.org/10.3390/ijgi4010124

[35] Geurs, K.T. and Van Wee, B. (2004) Accessibility Evaluation of Land-Use and Transport Strategies: Review and Research Directions. Journal of Transport Geography, 12, 127-140. https://doi.org/10.1016/j.jtrangeo.2003.10.005

[36] Ingram, D.R. (1971) The Concept of Accessibility: A Search for an Operational Form. Regional Studies, 5, 101-107. https://doi.org/10.1080/09595237100185131

[37] Iacono, M., Krizek, K.J. and El-Geneidy, A. (2010) Measuring Non-Motorized Accessibility: Issues, Alternatives, and Execution. Journal of Transport Geography, 18, 133-140. https://doi.org/10.1016/j.jtrangeo.2009.02.002

[38] Bocarejo, S.J.P. and Oviedo, D.R. (2012) Transport Accessibility and Social Inequities: A Tool for Identification of Mobility Needs and Evaluation of Transport Investments. Journal of Transport Geography, 24, 142-154. https://doi.org/10.1016/j.jtrangeo.2011.12.004

[39] Reggiani, A., Bucci, P. and Russo, G. (2011) Accessibility and Impedance Forms: Empirical Applications to the German Commuting Network. International Regional Science Review, 34, 230-252. https://doi.org/10.1177/0160017610387296

[40] Karou, S. and Hull, A. (2014) Accessibility Modelling: Predicting the Impact of Planned Transport Infrastructure on Accessibility Patterns in Edinburgh, UK. Journal of Transport Geography, 35, 1-11. https://doi.org/10.1016/j.jtrangeo.2014.01.002

[41] Geurs, K.T. and Ritsema van Eck, J. (2001) Accessibility Measures: Review and Applications. Evaluation of Accessibility Impacts of Land-Use Transportation Scenarios, and Related Social and Economic Impact. RIVM Report 408505 006, National Institute of Public Health and the Environment, Bilthoven. 
[42] De Smith, M.J., Goodchild, M.F. and Longley, P.A. (2015) Geospatial Analysis: A Comprehensive Guide to Principles, Techniques, and Software Tools. 5th Edition. http://www.spatialanalysisonline.com/HTML/

[43] Adriaensen, F., et al. (2003) The Application of "Least-Cost" Modelling as a Functional Landscape Model. Landscape and Urban Planning, 64, 233-247. https://doi.org/10.1016/S0169-2046(02)00242-6

[44] Grilo, C., et al. (2011) Do Well-Connected Landscapes Promote Road-Related Mortality? European Journal of Wildlife Research, 57, 707-716. https://doi.org/10.1007/s10344-010-0478-6

[45] Nolan, K.C. and Cook, R.A. (2012) A Method for Multiple Cost Surface Evaluation of a Model of Fort Ancient Interaction. In: White, D.A. and Surface-Evans, S.L., Eds., Least Cost Analysis of Social Landscapes: Archaeological Case Studies, University of Utah Press.

[46] Teng, M., et al. (2011) Multipurpose Greenway Planning for Changing Cities: A Framework Integrating Priorities and a Least-Cost Path Model. Landscape and Urban Planning, 103, 1-14. https://doi.org/10.1016/j.landurbplan.2011.05.007

[47] Rayfield, B., Fortin, M.-J. and Fall, A. (2010) The Sensitivity of Least-Cost Habitat Graphs to Relative Cost Surface Values. Landscape Ecology, 25, 519-532. https://doi.org/10.1007/s10980-009-9436-7

[48] Ortega, E., et al. (2014) Urban Fragmentation Map of the Chamberí District in Madrid. Journal of Maps, 1-10.

[49] Ministry of Tourism Israel (2014) Incoming Tourism Survey: 2013 Annual Report. Mertens-Hoffman Management Consultants, Ltd. (In Hebrew) 